Article

\title{
User's Lifestyle and the Thermal Performance of the Compound House: An Appraisal
}

\author{
Olugbenga S Fashuyi ${ }^{1, *}$ and Mohammed T Alfa ${ }^{2}$ \\ 1 Architecture, Girne American University, Kyrenia 99258, Turkey \\ 2 Architecture, Cyprus International University, Lefkosa 99428, Turkey \\ * Correspondence: olugbengastephen.fashuyi@std.gau.edu.tr; Tel.: +90-533-852-5360
}

Received: 2 May 2019; Accepted: 21 June 2019; Published: 28 June 2019

\begin{abstract}
This study examines the impact of thermal performance of Yoruba compound house on the user's lifestyle to cope with discomfort hours. A compound house was simulated using Autodesk Ecotect software. The study found that the front and right sides of the building have the lowest temperatures due to the combined effects of indirect and interzonal heat transfers. The research highlighted that while the user's lifestyle in the Yoruba compound house relies on the veranda to cope with discomfort hours, residents of multi-dwelling compound houses rely on a lifestyle of housing adjustments. The study concludes that the thermal properties of the Yoruba compound house are complemented by the user's lifestyle to cope with the discomfort hours.
\end{abstract}

Keywords: Yoruba; compound house; discomfort hours; housing adjustment; lifestyle

\section{Introduction}

In several parts of the world, traditional architecture is known to be inherently adapted to natural conditions [1]. It also possess physical adaptive qualities manifested in their form, thermal mass, material of composition, and space organization-all of which make traditional architecture climate responsive and user adaptable [2]. However, these natural features do not sufficiently meet user's requirements. Its thermal mass for instance, provides passive cooling [3], but often needs to be enhanced for better thermal performance. Stazi et al., stressing this point, observed that thermal performance in traditional buildings is improved by insulation [4]. However, when the insulating layer is about $9-\mathrm{cm}$ thick, the internal surface temperature may increase as much as $3{ }^{\circ} \mathrm{C}$, which is good for winter, but causes severe overheating in summer $[5,6]$. This highlights the weakness of the method. As a result, user's lifestyle in traditional buildings has emerged as recourse to improving its thermal performance. Thus, Kvisgaard and Collet [7] found that lifestyles relating to the operations of windows and doors enhance thermal performance by providing $63 \%-87 \%$ of the total air change per hour in adventitious or naturally-ventilated traditional buildings. These reinforce earlier studies concluding that traditional buildings, in their material compositions alone, do not sufficiently meet user's needs $[8,9]$.

Indeed, aspects of the user's lifestyle that enhance thermal performance in the "compound house" (which is a form of traditional architecture; see $[10,11]$ to meet their needs have been documented in some cases. Notable examples are Iranian and Afghan compound houses, where the lifestyle does manifest in the form of housing adjustments in the compound consisting of flocks of houses completely detached from each other but within the same compound (multi-dwelling compound house) (Figure 1). The influence of lifestyle experiences on the thermal performance of users in the one-dwelling compound house, however, remain understudied. In studying the Yoruba compound house (Figure 2), this research attempts to contribute to knowledge in this area by evaluating the impact thermal performance on the user's lifestyle to cope with discomfort hours in a one building 
compound house. The Yoruba compound house is an example of a one-building compound house-a flock of houses separated by rooms and courtyards but maintained as one building.

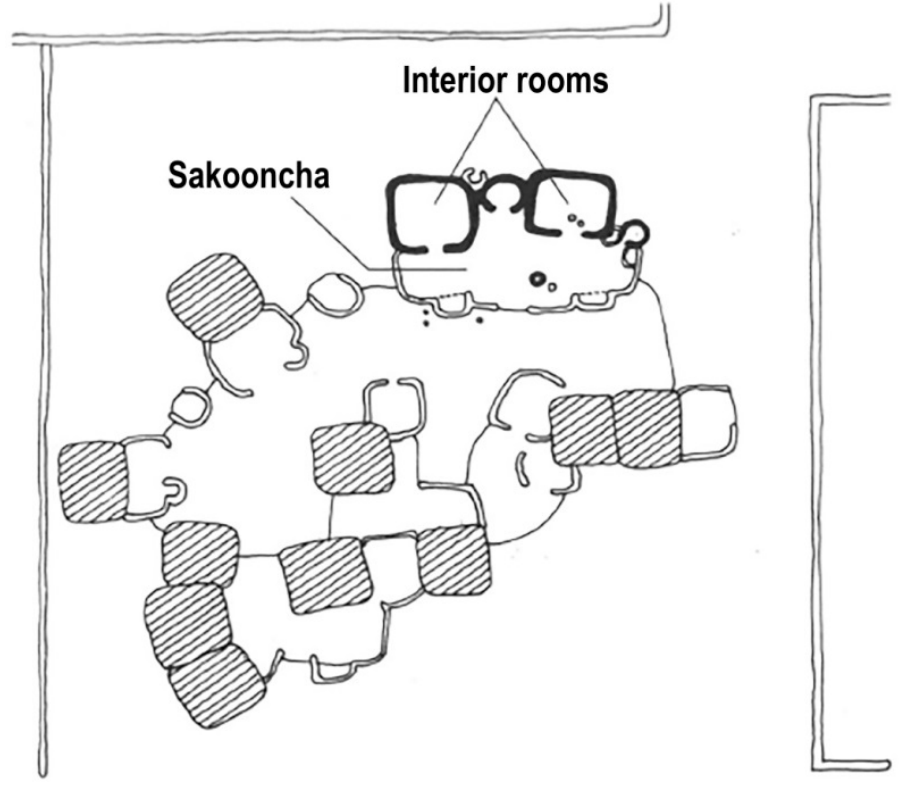

Figure 1. Afghan compound house. * Within the traditional Afghan courtyard, the sakooncha, a solid platform half a meter high, allows people to sit above the level of circulation [12].

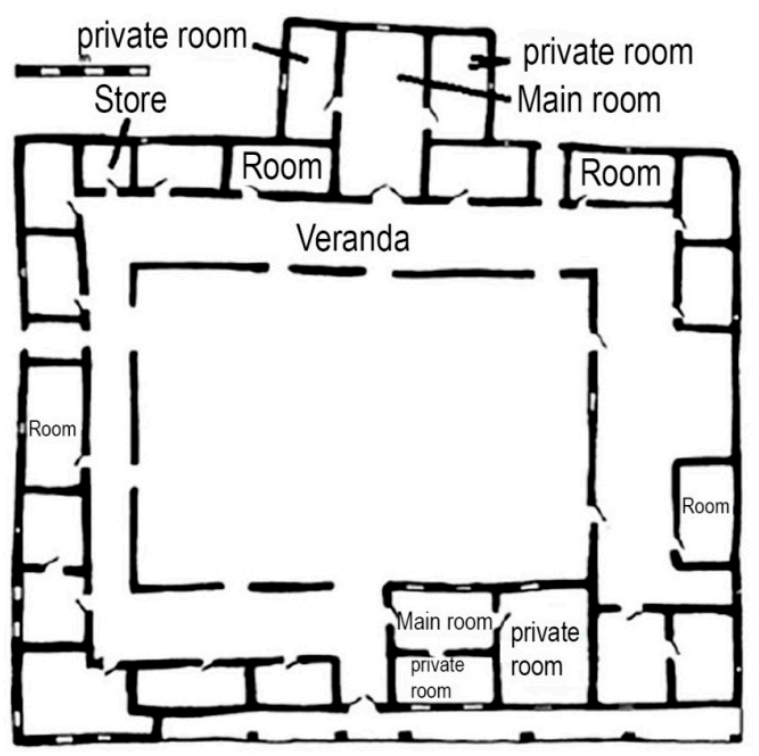

Figure 2. Yoruba compound house.

\section{The Yoruba Compound House}

The compound house is a very plain undecorated structure within a dense urban geometry which influences its ambient temperatures [13] by reducing the ventilation outside the compound house [14]. Usually, the building is in the form of a hollow square horseshoe and features a large single courtyard (Scheme 1) and may house between 100-200 residents [15]. Moreover, it has a main entrance at the front of the house as well as another back entrance. The back entrance leads to ancillary facilities such as lean-to sheds which are used as kitchens and conveniences. 


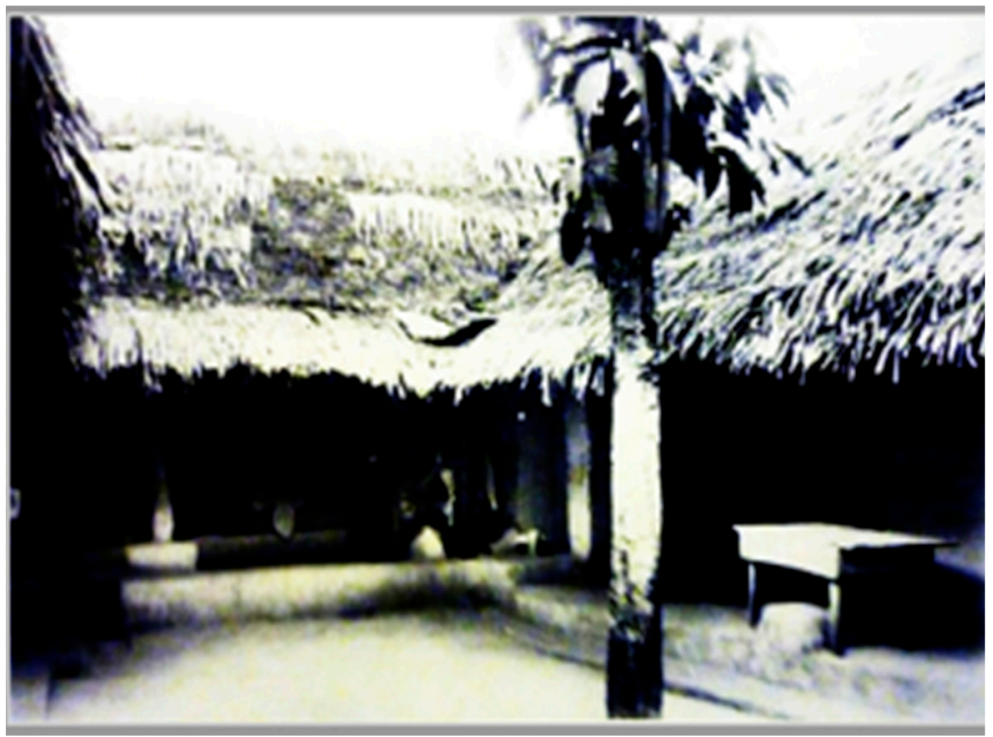

Scheme 1. Yoruba traditional compound house.

\subsection{Climate and Location}

The Yoruba homeland is in the south-western part of Nigeria and includes virtually the whole of Lagos, Ogun, Ondo, and Oyo States, as well as the south-eastern parts of Kwara State. In the north-west it extends across the Benin Republic into Central Togo (Figure 3). This area falls within the tropical wet and dry (AW), according to Koppen-Geiger climate classification, with temperatures that can reach a minimum of $20^{\circ} \mathrm{C}$ and maximum of $34^{\circ} \mathrm{C}$ through the year. The dry season sets in from November to February while the rainy season is from March to October.

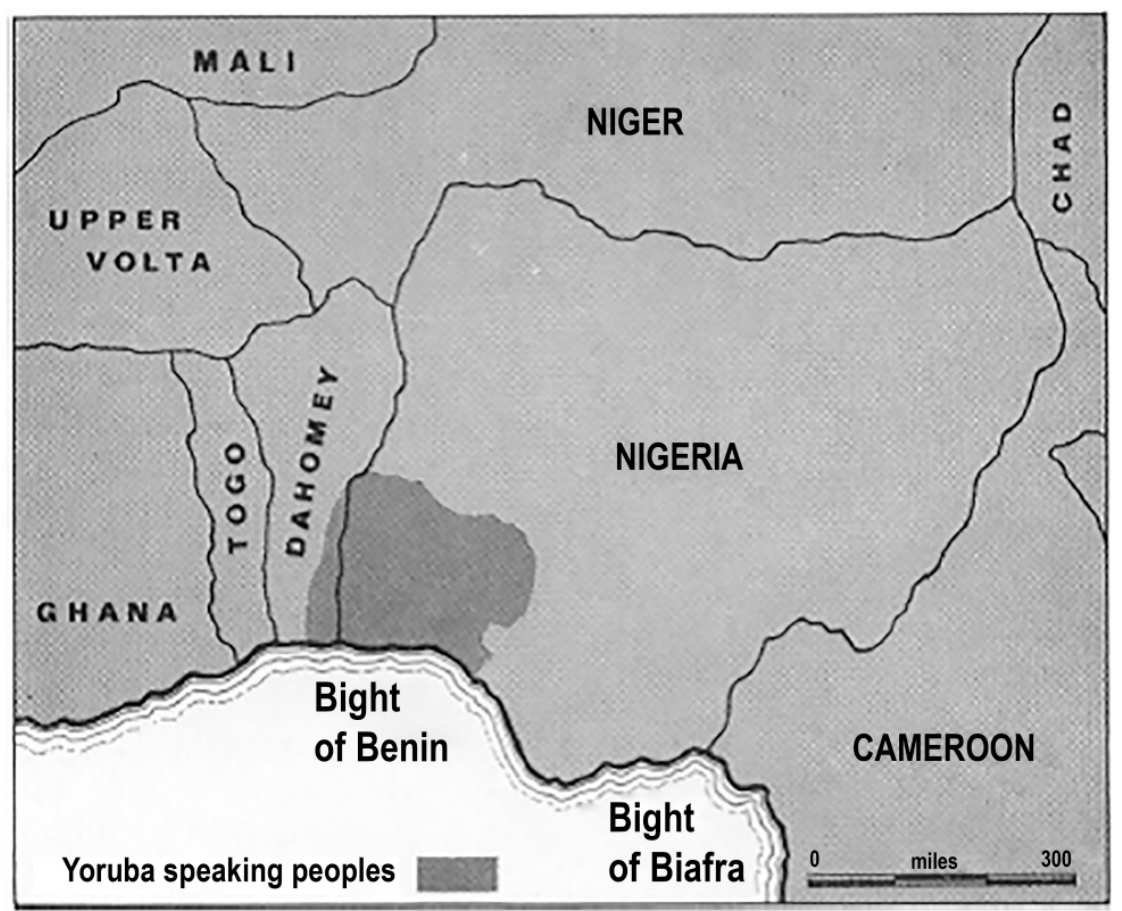

Figure 3. Location of study area. 


\subsection{Structure and Thermal Properties}

The rammed earth structure was built by compressing a damp mixture of earth (gravel-15\%, sand $-50 \%$, and clay-35\%) into an externally supported frame to create solid walls $[16,17]$. The structure and thermal properties were examined considering the following:

\subsubsection{The Wall}

The rammed earth wall was built gradually, stopping after every $0.45-0.6 \mathrm{~m}$ to allow the rammed earth to dry for a few days. It was about $30 \mathrm{~cm}$ thick and in the course of building, roughly trapezoidal doorways and window-openings were left at various intervals. With the heat storage capacity of $1830 \mathrm{KJ} / \mathrm{m}^{3} \mathrm{~K}$ [18], the wall absorbed and stored heat when exposed to solar radiation, to release it to the environment when the surrounding temperature dropped. This resulted in negative heat flow and a negative coefficient of heat transfer [19].

\subsubsection{The Door}

The doors were about $0.45 \mathrm{~m}$ wide and $1.2 \mathrm{~m}$ high and were constructed of soft inner part of palm branches or straw held together by a number of palm fronds. The straw was used in the region of the Guinea savanna while the palm fibers were used in the coastal belt where there is more rainfall. Both materials (straw and palm fibers), allowed the movements of air to the rooms. The palm fiber has a very high specific heat capacity of $27.1 \mathrm{~kJ} / \mathrm{kg} \mathrm{K}$ and very low thermal diffusivity of $0.21\left(\times 10^{-7} \mathrm{~m}^{2} \mathrm{~s}^{-1}\right)$ (Table 1) which enhance good insulation characteristics and passive design [20-22].

\subsubsection{The Floor}

The adobe floors characterize the compound house unlike concrete in more modern houses. From Table 1, the conductivity of $110 \mathrm{~mm}$ thick of adobe is $1.7 \mathrm{~W} / \mathrm{m} . \mathrm{K}$ while its density is $1698 \mathrm{~kg} / \mathrm{m}^{3}$ and specific heat is $1.01 \mathrm{KJ} / \mathrm{kg} . \mathrm{K}$ (Table 1 ). Concrete with a similar conductivity would have a specific heat between 0.8 to $1.0 \mathrm{KJ} / \mathrm{kg} . \mathrm{K}$ [23] which indicates that adobe, absorbs more heat than concrete even when it is less dense and in spite of concrete's embodied energy.

\subsection{Spatial Characteristics}

\section{One-Sided Ventilated Rooms}

The compound house was a single-sided row of rooms and ancillary facilities arranged around a veranda that leads to a courtyard. While the rooms $(2.8 \mathrm{~m} \times 3.0 \mathrm{~m})$ had small windows $(0.30-0.45 \mathrm{~m})$ on the external walls, there were no windows (only doors) in the interior walls. The doors to the rooms were either a semi-permeable curtain made of the soft inner part of palm branches, or straw which allowed air movements through them. Hence, the doors conceptually serve as windows to ventilate the rooms, making the rooms single-sided ventilated. Indeed, [24,25] concluded that the veranda, by creating variations in the pressure distribution on the interior wall facades and by acting as a transitional space between the indoor and outdoor environment improves indoor airflow in the rooms in such one-sided ventilated buildings [26-32].

\section{User's Lifestyle}

\subsection{User's Lifestyle: The Yoruba People}

The Yoruba people are predominantly farmers and craftsmen [33,34]. Thus, their daily activity is simple. It involves waking up early (as early as 5:00-5:30) for farm work while the craftsmen start preparation for daily routines. At about 13:00-14:00, the farmers return; all through this period, the aged and older women stay indoors and look after the house (see Figure 14). Their industry in crafts is practiced along the verandas in the compound. They are also convivial which underscores a lifestyle showing a readiness to receive visitors. They welcome their guests along the veranda in the daytime 
and enjoy the narration of the folktales, singing, drumming, and dances in the courtyards when the sunset and evening periods. For these reasons, the courtyard may be 90 square meters to 900 square meters and the veranda about 2.1 meters wide.

\subsection{User's Lifestyle: Iranian and Afghan Case Studies}

\section{A Lifestyle of Housing Adjustment}

In the Iranian compound houses, no part of the compound house is occupied all at once due to intensive summer sun and times of major seasonal temperature differences [12]. The attitude of the occupants to this is housing adjustment by moving their accommodation [35] to different locations amongst the several dwellings in the compound (See Figure 2). For example, during the summer months and the warmer autumn, they have their main living quarters on the south side because of its shade. The north side of the courtyard, which is warmed by low winter sun, is most suitable for the winter months. As a result, a unique itinerant lifestyle emerges.

Amongst the Afghan, the summer months mark the beginning of adjustments, as the inhabitants' set up their itinerant in a clockwise rotation following the shade provided by the huts and other screening features. A typical itinerary is illustrated by the activity sequence in the compound. In the morning, the women, old people, and children gather in the eastern part of the courtyard while the men go to work. At noon, lunch is eaten in the southern sector; afterwards activity moves to the western areas where the preparation of dinner commences. By late afternoon the males have returned home, and dinner is served collectively or individually afterwards. In winter, these patterns are altered (in that they take advantage of the warmth of the sun during the day) and the result is that many activities are brought indoors, with the remaining outdoor activities still following the existing pattern.

\section{Thermal Performance Evaluation and Result}

\subsection{Materials and Methods}

The main goal of this paper is to show how the thermal performance of the Yoruba compound house (the indirect and interzonal heat transfers which are affected by thermal properties of its rammed earth walls and the air change per hour (ach) influences user's lifestyle in the building to cope with discomfort hours. Hence, the analyses are in two sections which are: i) thermal performance analyses of the compound house and ii) evaluation of the user's lifestyle within the compound house. The latter has been examined in Section 3.

The analysis of the former involved the simulation and report of annual discomfort degree hours and energy loads (cooling/heating loads) in the compound house. In order to do this, the compound was divided into 20 zones (Figure 4) which are the number of rooms and doorways in Figure 1 above. The study employs Autodesk Ecotect 2011 in the simulation. The Autodesk Ecotect is environmental analysis software that incorporates an interactional platform and analysis operation functions to simulate thermal performance from the nascent stage of a building's conceptual design. Thermal parameters such as infiltration condition, thermal resistivity and transmittance of the rammed earth wall (R-and U-values) the wind speed and relative humidity at the study area are used by the software for the simulation (Table 1). 
Table 1. The simulation parameters.

\begin{tabular}{|c|c|c|c|c|c|c|}
\hline Material & $\begin{array}{c}\text { Density, } \rho \\
\left(\mathrm{kg} / \mathrm{m}^{3}\right)\end{array}$ & $\begin{array}{c}\text { Thermal } \\
\text { Conductivity, } \lambda \\
\left(\mathrm{W} \mathbf{m}^{-1} \mathrm{~K}^{-1}\right)\end{array}$ & $\begin{array}{l}\text { Diffusivity, } \\
\alpha\left(\times 10^{-7} \mathrm{~m}^{2}\right. \\
\left.\mathrm{s}^{-1}\right)\end{array}$ & $\begin{array}{c}\text { Specific Heat } \\
\text { Capacity, } \lambda / \alpha \rho \\
(\mathrm{kJ} / \mathrm{kg} \mathrm{K})\end{array}$ & $\begin{array}{l}\text { U-Value } \\
\left(\mathrm{W} / \mathrm{m}^{2} \mathrm{~K}\right)\end{array}$ & $\begin{array}{l}\text { R-Value } \\
\mathrm{m}^{2} \mathrm{~K} / \mathrm{W}\end{array}$ \\
\hline * Straw & 60 & 0.067 & 18.2 & 0.600 & - & - \\
\hline ** Rammed earth & $\begin{array}{c}1540 \\
(300 \mathrm{~mm})\end{array}$ & 1.25 & 3.93 & 1.260 & 2.86 & $0.3-0.7$ \\
\hline$* * *$ Adobe floor & $\begin{array}{c}1698 \\
(110 \mathrm{~mm})\end{array}$ & 1.7 & 2.7 & 1.005 & 2.62 & 0.6 \\
\hline$* * * *$ Palm fiber & 797 & 0.09824 & 0.21 & 27.095 & - & - \\
\hline
\end{tabular}

For the analysis, humidity was $50 \%$, wind speed was $0.13 \mathrm{~m} / \mathrm{s}$ and the comfortable room temperature band was $23{ }^{\circ} \mathrm{C}-26{ }^{\circ} \mathrm{C}$ according to the International Standard Organization (ISO) recommendations [39]. The weather data for the study area, Lagos Nigeria, are used for the analysis. The data are available in the Energy Plus Weather format (EPW) and were converted to the Ecotect Weather file format (WEA) for the simulation.

\subsection{Thermal Analyses of the Compound House}

This was undertaken under the following subheadings.

\subsubsection{Total Solar Gain in the Compound}

The best orientation for the building was calculated to be $12.5^{\circ}$ from the north using an orientation tool in Autodesk Ecotect software. Thereafter, the total annaul solar radiation on the building was found to be between $0.09 \mathrm{MWh} / \mathrm{m}^{2}-1.8 \mathrm{MWh} / \mathrm{m}^{2}$ (Figure 4).

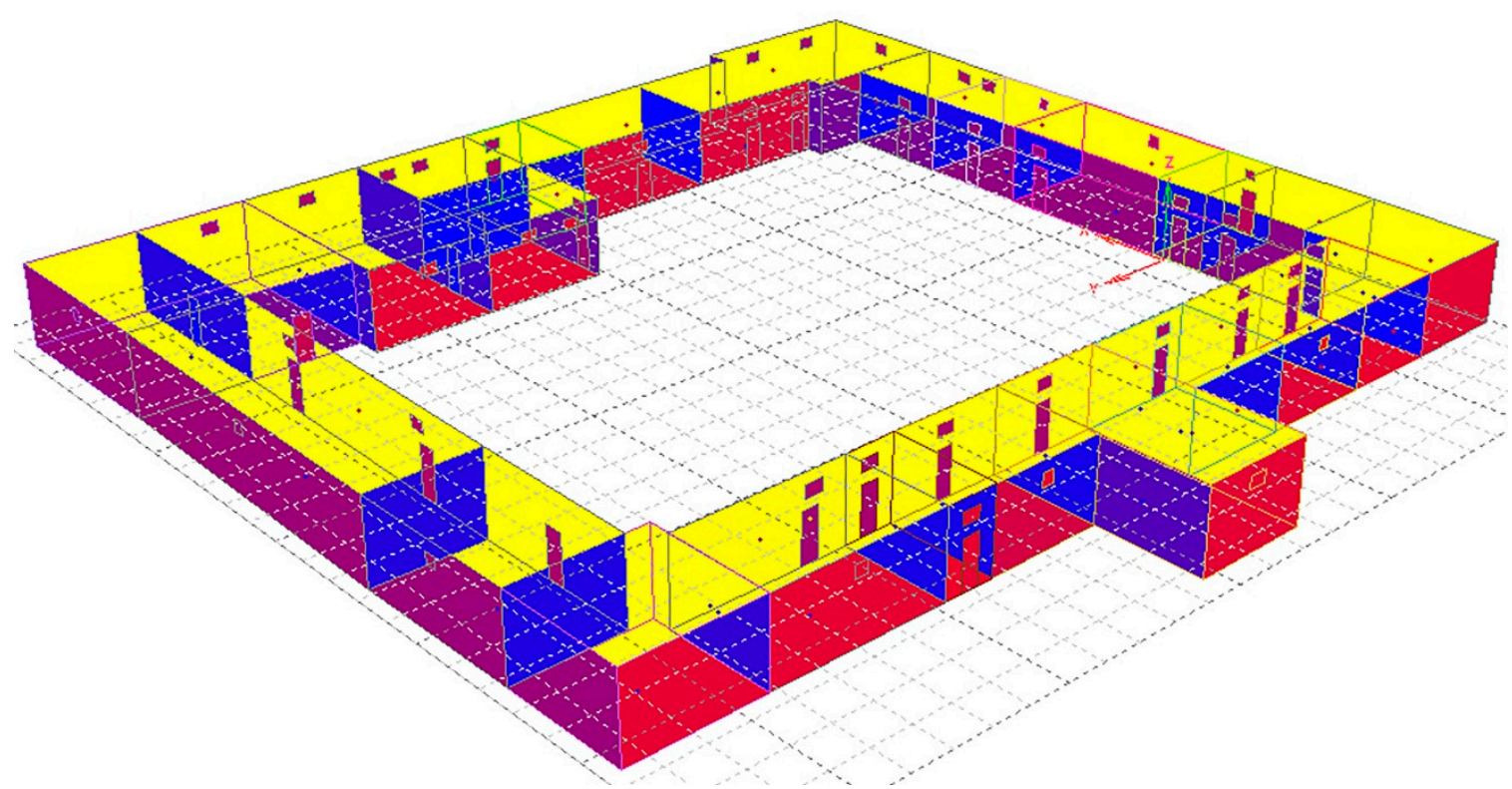

Figure 4. The compound zones.

\subsubsection{Energy Simulation: Discomfort Degree Hour and Cooling Loads}

The annual discomfort degree hour is 25355.9 hours resulting in $51.3 \%$ of the annual degree hours. The annual cooling load to maintain the building within the comfort band is $21.64 \mathrm{MWh} \mathrm{Wh} /$ $0.08 \mathrm{MWh} / \mathrm{m}^{2}$ (total floor area is $268.6 \mathrm{~m}^{2}$ ). No heating load was required (Figure 5). The cooler months (that requires lower amount of cooling loads) are between June and November (Figure 6) and they are 
all within the rainy season except November. The hot periods (with higher cooling load requirements) are in the dry season except the months of April and May (Figure 5).

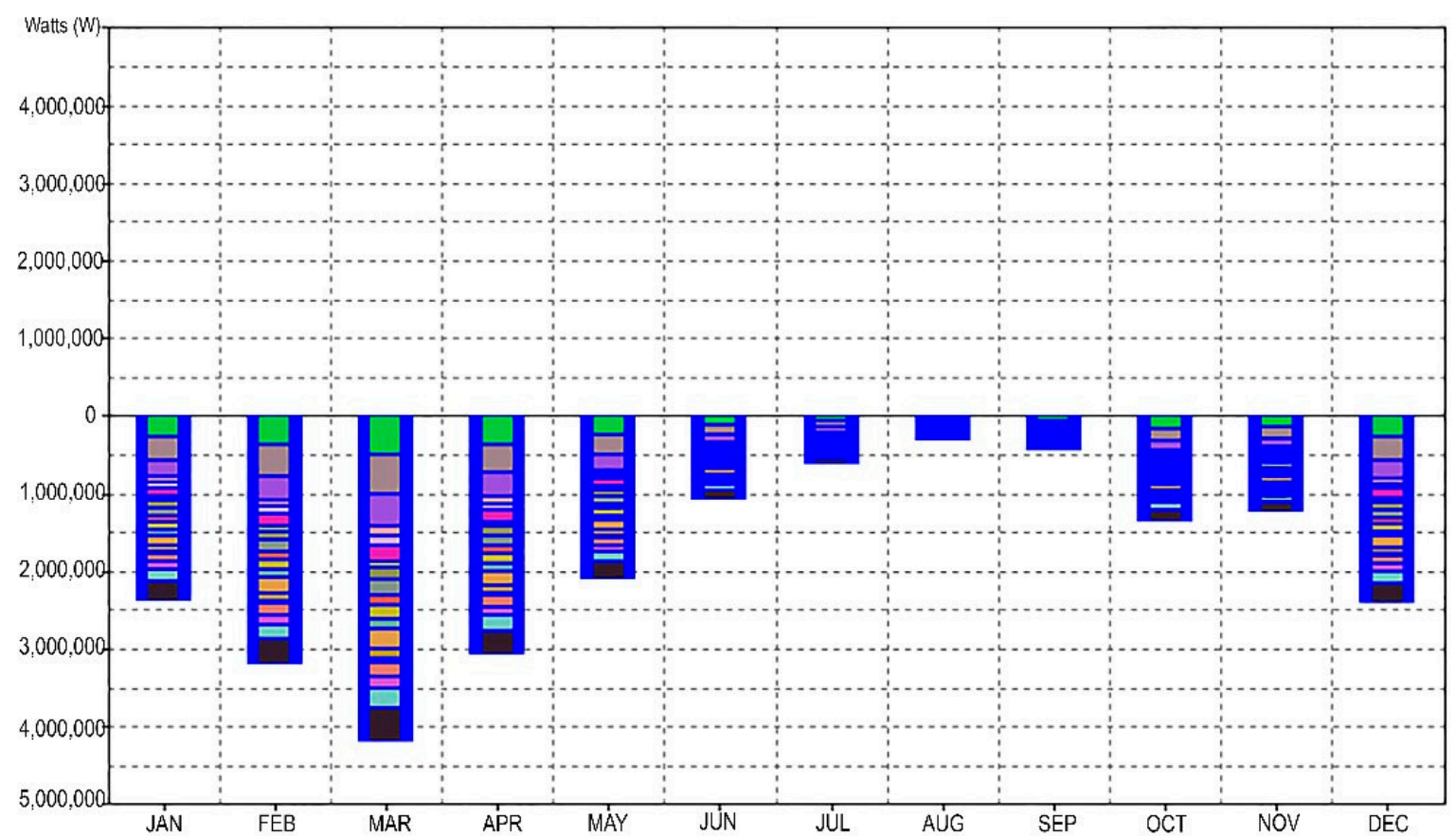

Figure 5. Cooling loads.

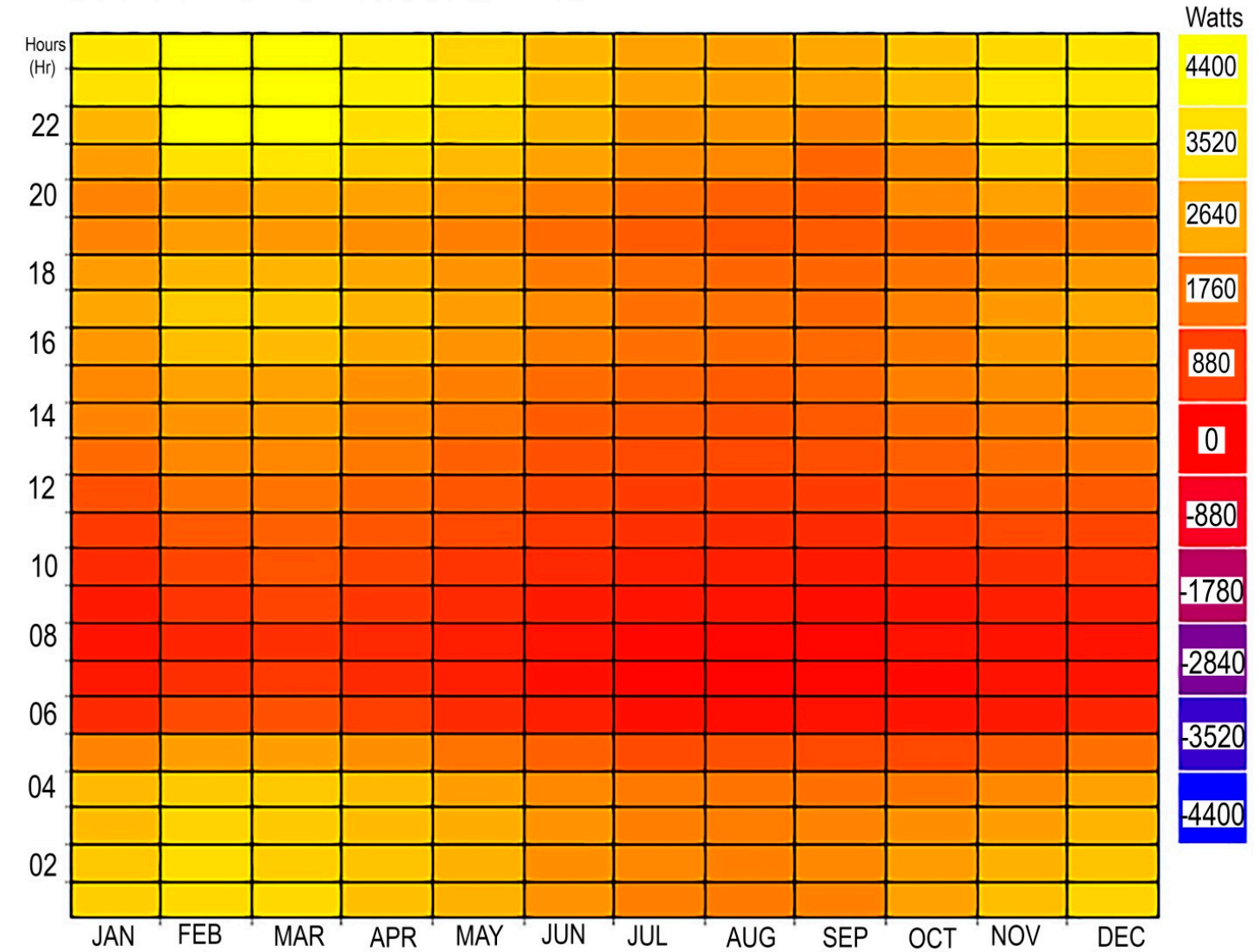

Figure 6. Effect of thermal mass on heat gain/loss in rammed earth. 


\subsubsection{The Compound House Thermal Mass}

The simulation (Figure 6) analyses the impact of thermal mass on the heat gains and losses in the compound house. The graph displays an average day each month, with months along the horizontal axis and hours of the day along the vertical. The color of each grid square represents the average gain or loss. It is observed that the least heat gains (mainly 0-0.08 KW) are between the hours of 8:00 and 18:00. This period was found to correspond to the highest outside temperatures between 8:00-18:00 (Figure 7).

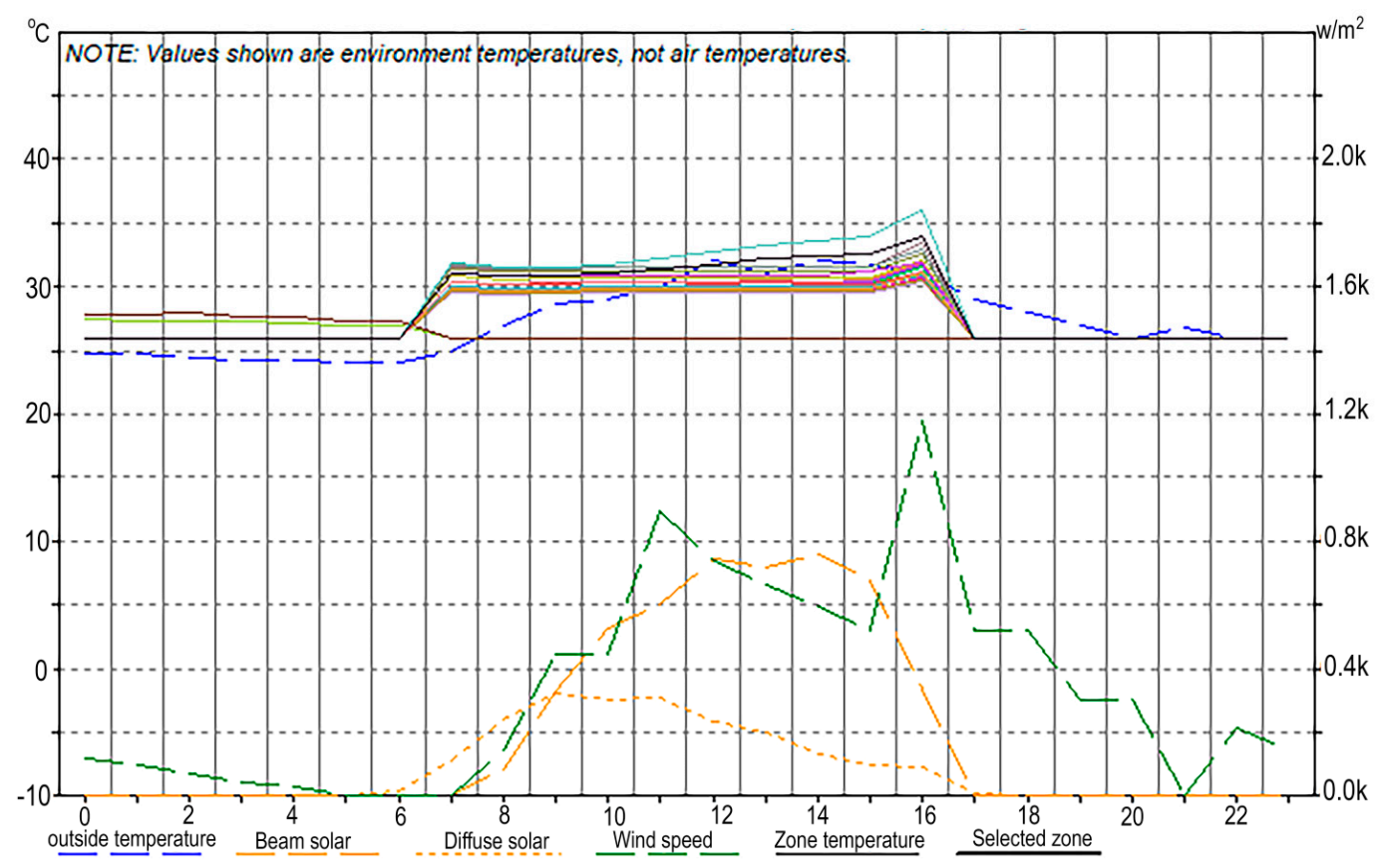

Figure 7. Average daily hourly temperatures in the study area.

Indirect Solar

Figure 8 reports the simulation of indirect solar. The graph indicates that lowest gains occur between 6:00-16:00 (mainly 0-0.04 KW). Thereafter, heat gain increases. A further analysis (Figure 9) shows the effect of indirect solar on the four sides of the compound house. This is shown in in (Figure 9) below. Primarily, the analysis shows that indirect solar has a negative heat gain in rammed earth buildings. The incidence of a negative heat gain implies heat loss from the building to the environment (resulting in the negative coefficient of heat transfer). 


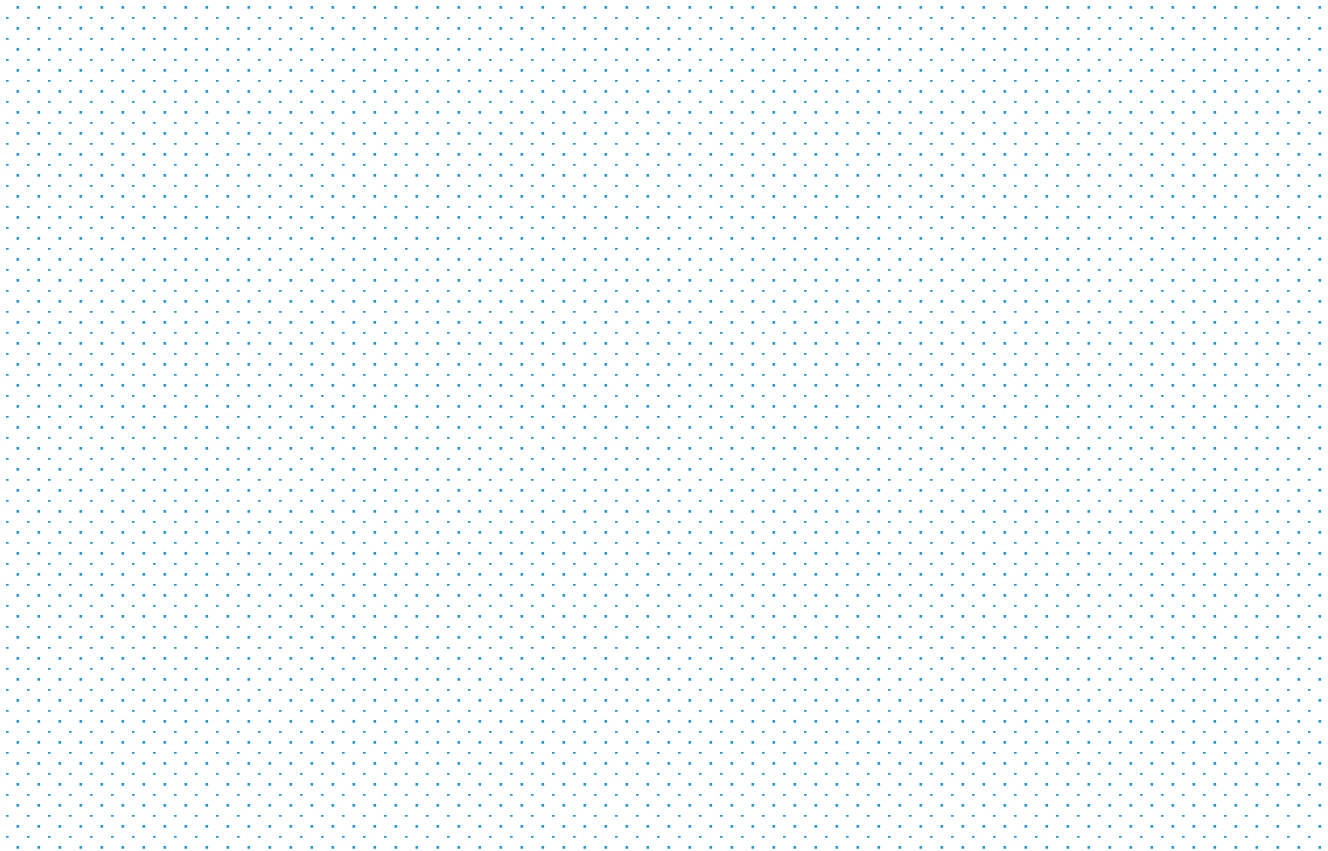

Figure 8. Heat gain/loss due to indirect solar in rammed earth.

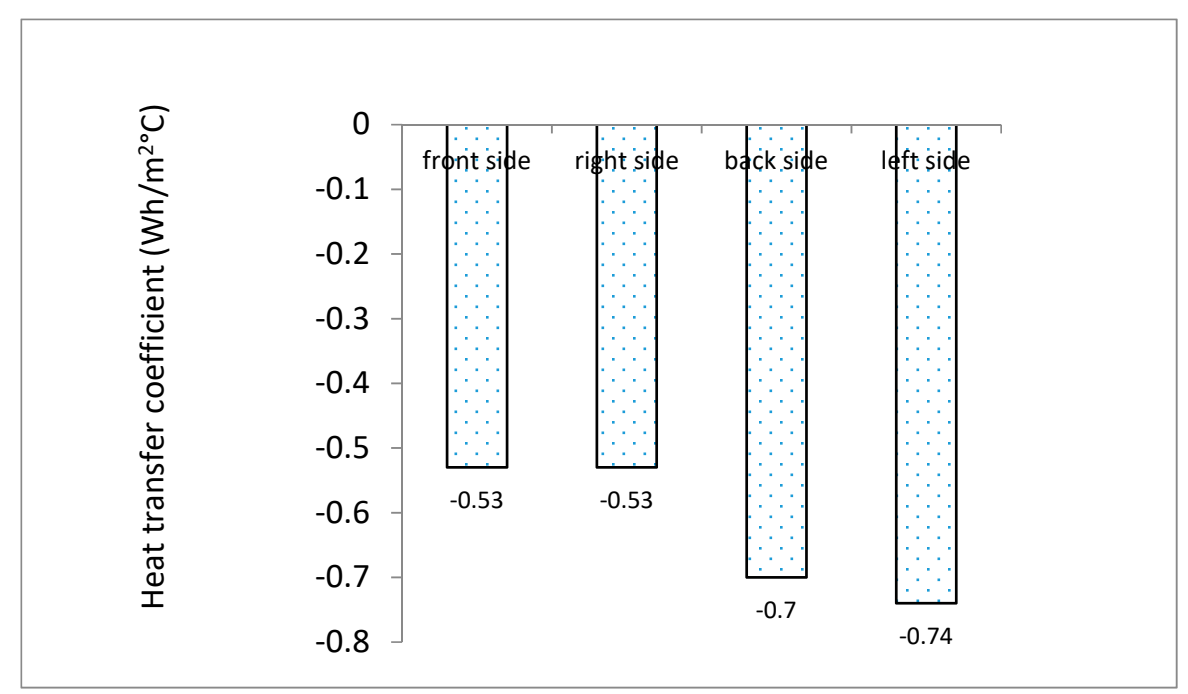

Figure 9. Heat gain/loss owing to indirect solar.

\section{Interzonal Heat Transfer}

Interzonal transfer occurs by conduction through the rammed earth wall partitions and doors between the rooms and is inversely proportional to the thermal resistance (R-value) of the walls and door partitions [40]. Figure 10 analyses the interzonal heat transfer in the rammed earth wall. The graph shows that interzonal transfer between 8:00 to 17:00 which results in heat loss (between $-1000 \mathrm{~W}$ to -200 W). Thereafter (from 17:00), interzonal heat gain occurs. From Figure 10, it is also observed that heat loss occurs at the time of rising outside temperature which is between 8:00-18:00. A further analysis (Figure 11) shows the effect of interzonal heat loss on the four sides of the compound house. 


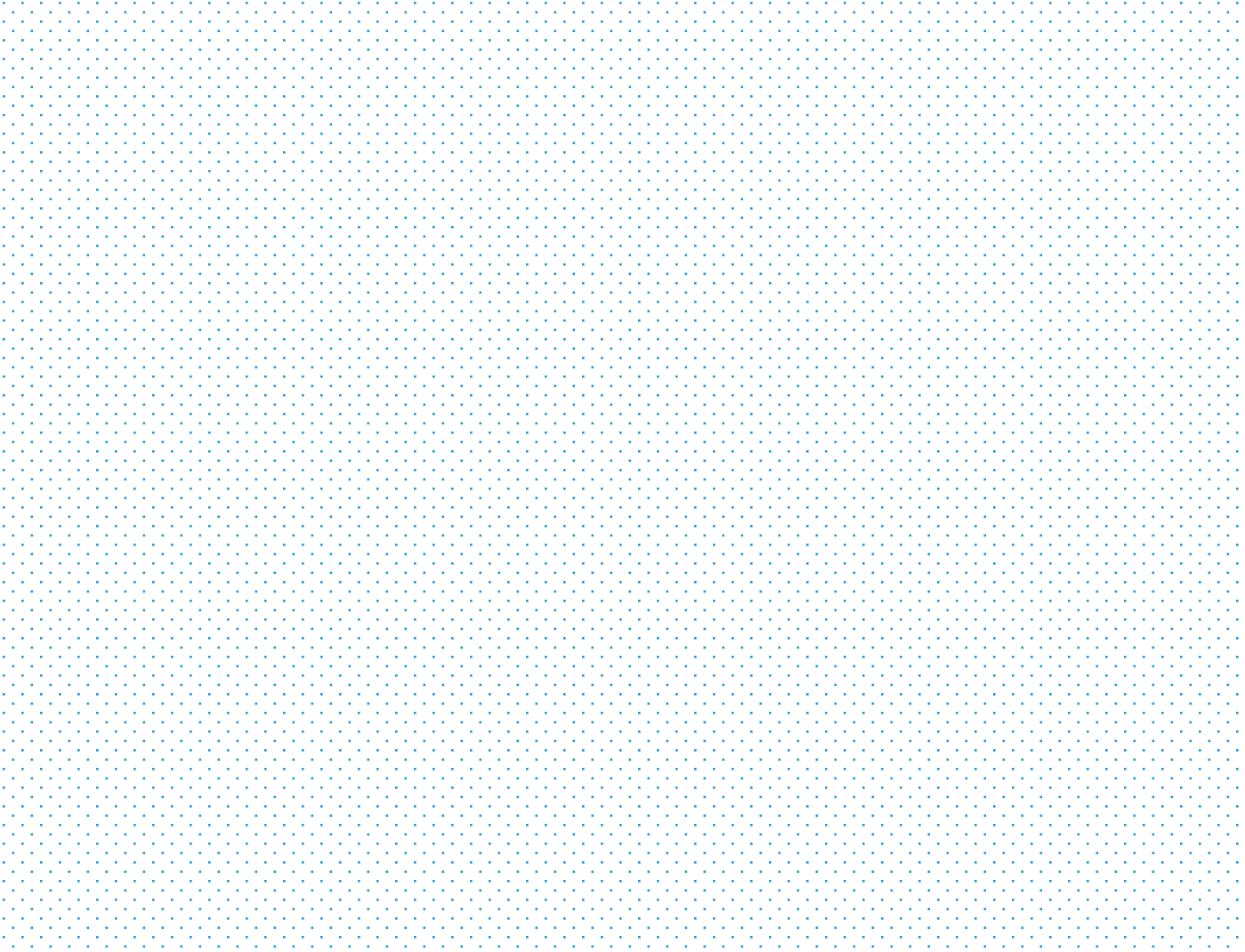

Figure 10. Interzonal heat transfer in the rammed earth.

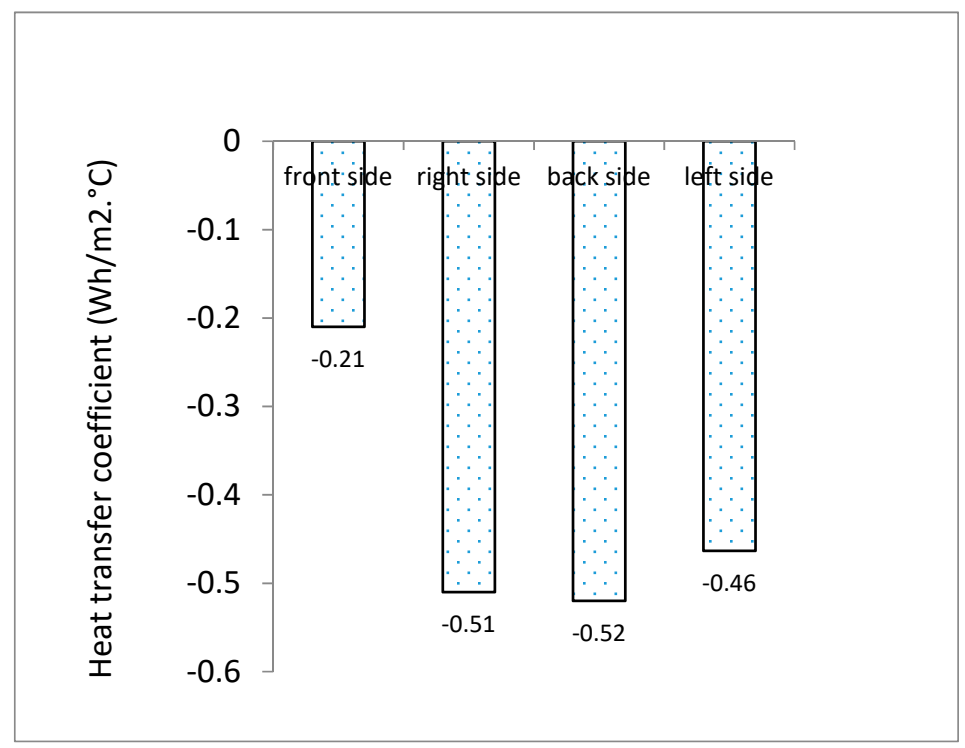

Figure 11. Interzonal heat loss at the four sides of the compound house.

\section{Discussion}

The heat gain as a result of indirect solar in the analysis is not the result of the outside temperature (since it is at night and after sunset) but mainly as a result of stored heat in the rammed earth due to its thermal mass, hence the negative coefficients of heat transfer in Figure 9. This helps in keeping the building warm at night and help keeps the it within the comfort temperature band when the outside temperature falls below $23^{\circ} \mathrm{C}$ (Figure 12) so that no heating load was required (Figure 6). This characteristic is congenial and enhances the thermal performance of the compound house. 


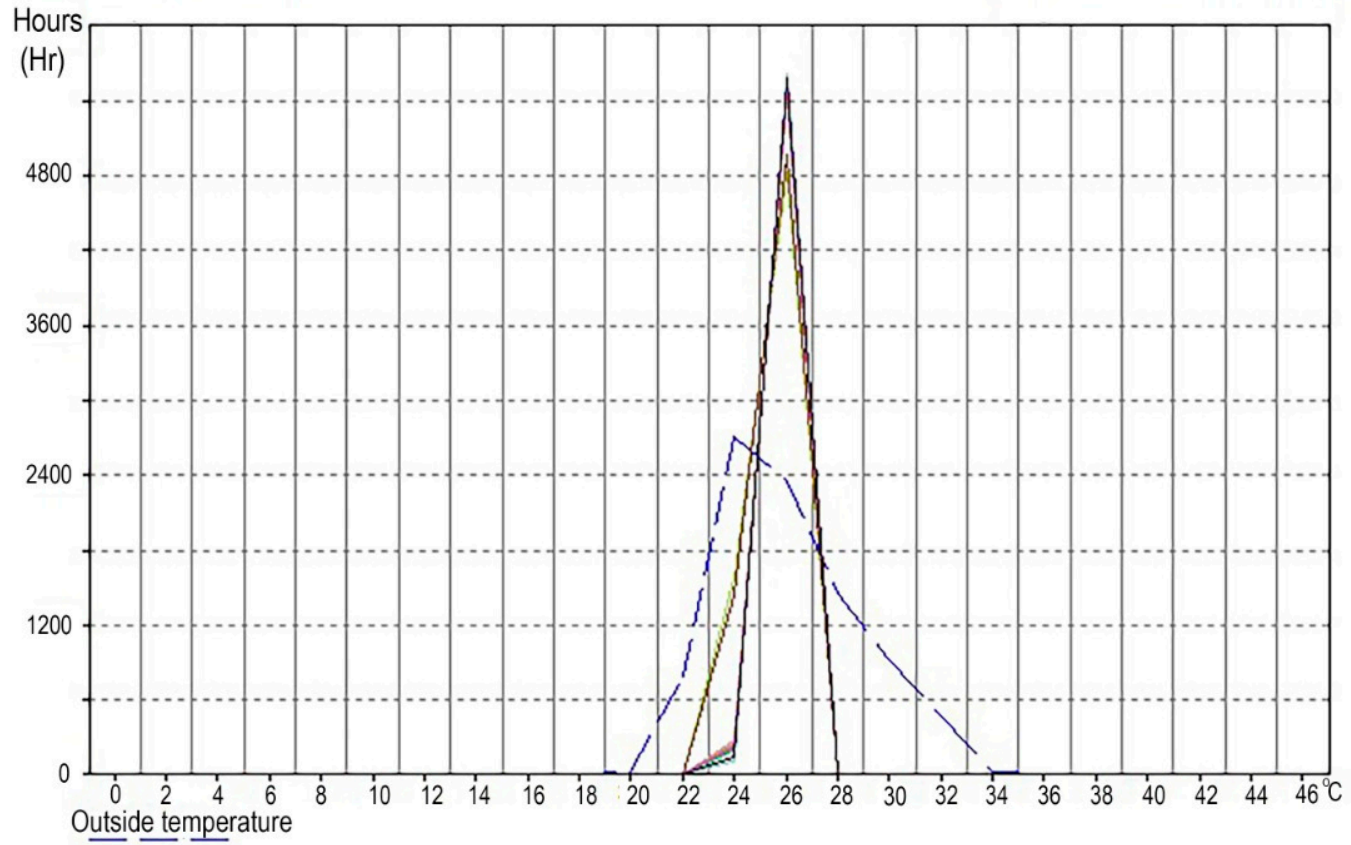

Figure 12. The outside temperature reaches as low as $20^{\circ} \mathrm{C}$ and as high as $34^{\circ} \mathrm{C}$. ${ }^{*}$ The 2 -lines within the outside temperature band represent the temperature band ( 2 zones) within the building. It is largely between $24-28{ }^{\circ} \mathrm{C}$ implying that the outside temperature has been moderated from $20-34{ }^{\circ} \mathrm{C}$ to $24-28^{\circ} \mathrm{C}$ as a result of the buildings' thermal mass.

This notwithstanding, indirect heat loss varies across the facades of the compound. As shown in Figure 9, the back elevation followed by the left have the highest coefficient of heat transfer while the front and right elevations have the least. This implies that there is higher rate of heat transfer from the back and left elevations to the environment. It further implies that the back and left elevations have the highest insolation and that the front and right elevations have the least. In spite of these, interzonal heat transfer is lowest in the right-side elevation and approximately equal amongst the other elevations $(-0.51,-0.52$, and -0.463 for right, back and left elevations respectively). As a result, the right side has the lowest temperature because of the combinational effects of low indirect heat and high interzonal negative heat transfer. Thus, users of the compound house use the veranda-side at the front and right elevations in the warmer periods of December to May (Figure 5). During the wet, harmattan and cold seasons, activities move towards the veranda-side at the back and left elevations because they are warmer.

Furthermore, Figures 7 and 12 shows that the outside temperature peaks at $34{ }^{\circ} \mathrm{C}$ between 8:00-17:00 which is when the interzonal heat losses occur. This is rewarding as it helps to ameliorate the effects of rising outside temperatures on the building during the peak periods. Thereafter (after 17:00) interzonal heat gains occur as mentioned earlier (Figure 10). User's response to the heat gain is indicated in Figure 14. From the graph, the percentages of users in the rooms drop from 50 to 25 between the hours of 5:00-19:00 which was as soon as the interzonal heat gains occur. Regardless of the heat gain however, the resultant heat transfer coefficient is negative (Figure 11) showing that heat lost by the compound house exceeded the heat gain; an attribute that contributes to its passive cooling and enhances its thermal performance.

Despite the passive cooling, the analysis show that a cooling load of 21.64 MWh was required to maintain the comfort temperature band in the building and that about half $(51.3 \%)$ the time spent by occupants in the building are discomfort hours. This load owes primarily to the internal heat gain in the compound house (Figure 13). User's responses to this manifest in their lifestyles within the compound house as the means of coping with the discomfort hours. 


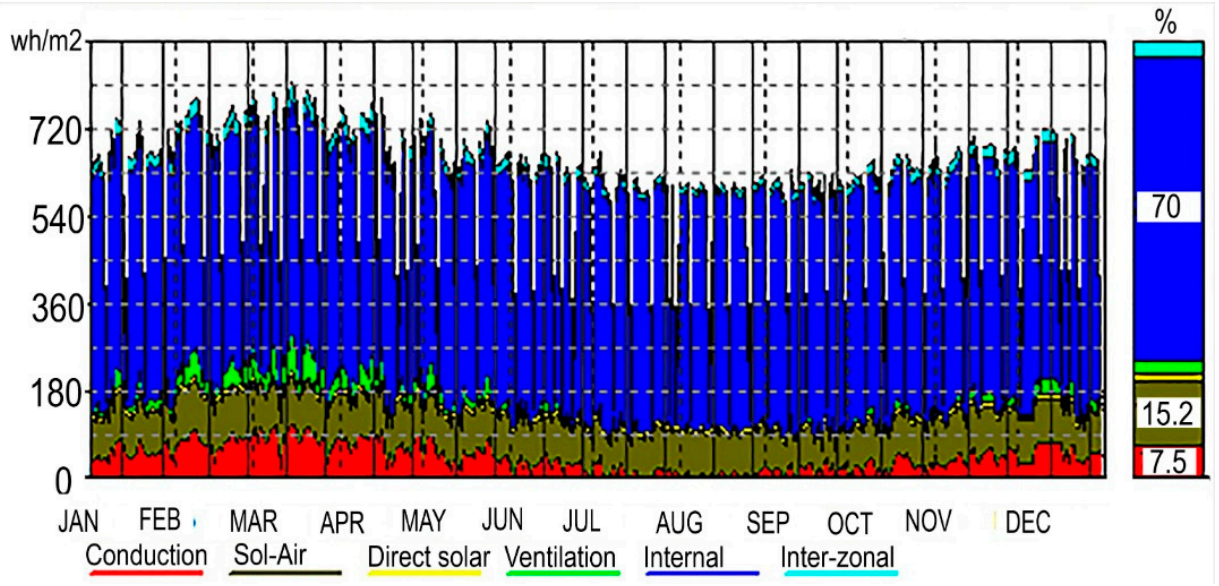

Figure 13. Heat gains breakdown.

The primary object of the building that served this vital role is the veranda. The veranda was observed to aid in cultivating useful lifestyles as a way to cope with the cooling load/discomfort hours. Indeed, such attitudes and behaviors relating to the culture of closeness amongst extended family members, pastimes, the welcoming of visitors and indoor mercantile activity on the veranda, helps residents to escape the indoor discomfort periods. Hence, a significant discomfort period is compensated by the user's lifestyle and activities on the veranda. In addition, some of the behavior of the compound residents relating to their practices of storytelling and dance further keep them away in the courtyards during discomfort hours. Aside from this, other residents of the compound house, especially the farmers, return from their farms after noon, to dedicate considerably hours for pastimes along the veranda. This convivial attitude further tends to relieve them from uncomfortable room conditions. Overall, the hourly schedule of the residents of a compound house is summed up in Figure 14 below. From the chart, the relatively few hours in the rooms are suited to life in a compound house to avoid discomfort hours which owes to internal heat. For clarity, the hourly distribution of residents in the rooms according to the graph is shown in Table 2.

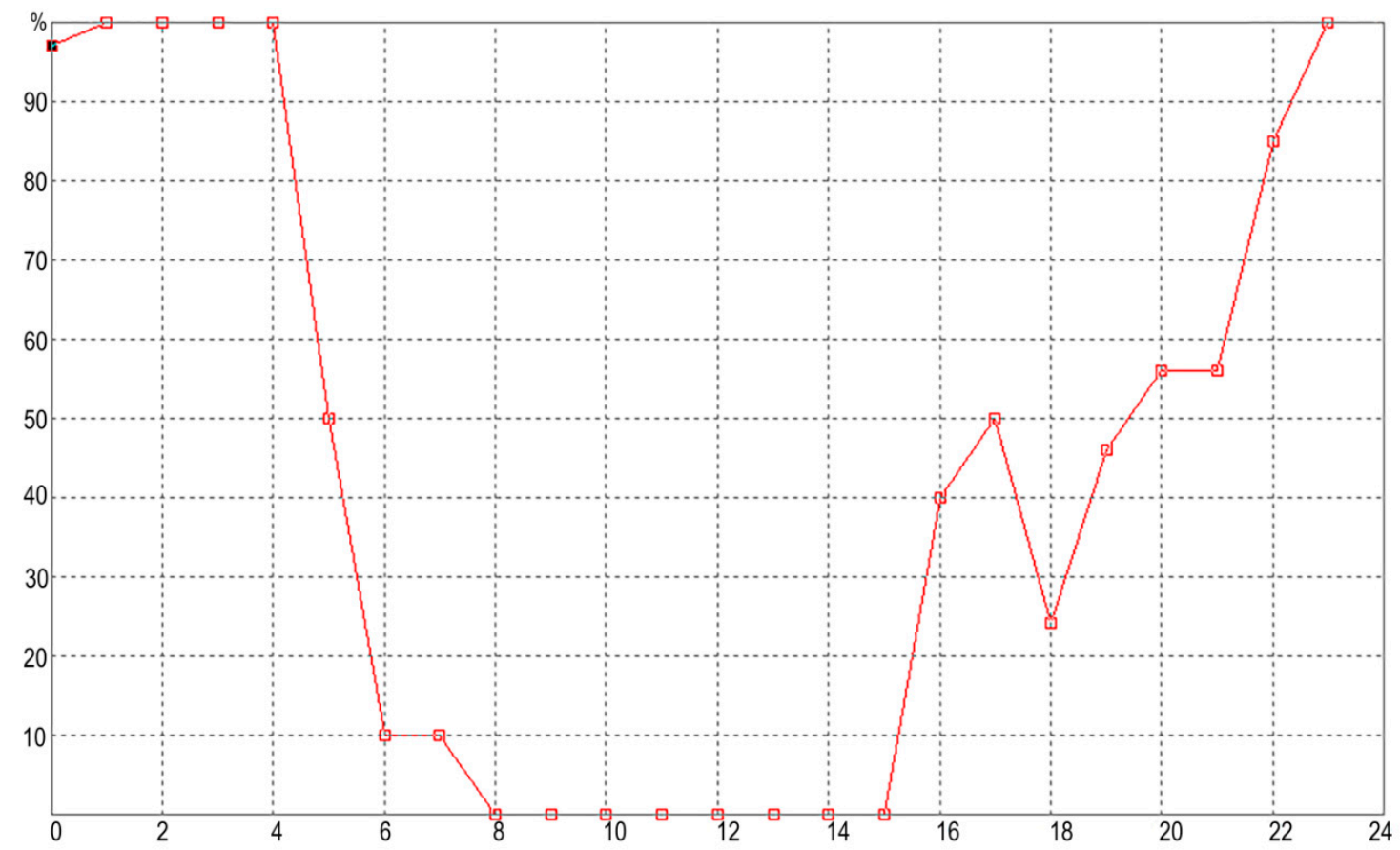

Figure 14. Room schedule. 
Table 2. Hourly schedule of the occupants/user's (\%) in the rooms.

\begin{tabular}{ccccccc}
\hline Hour & $\mathbf{0 0 : 0 0}$ & $\mathbf{0 1 : 0 0}$ & $\mathbf{0 2 : 0 0}$ & $\mathbf{0 3 : 0 0}$ & $\mathbf{0 4 : 0 0}$ & $\mathbf{0 5 : 0 0}$ \\
\hline Value $(\%)$ & $100: 00$ & $100: 00$ & $100: 00$ & $100: 00$ & $100: 00$ & $50: 00$ \\
\hline Hour & $06: 00$ & $07: 00$ & $08: 00$ & $09: 00$ & $10: 00$ & $11: 00$ \\
\hline Value $(\%)$ & $10: 00$ & $10: 00$ & $00: 00$ & $00: 00$ & $00: 00$ & $00: 00$ \\
\hline Hour & $12: 00$ & $13: 00$ & $14: 00$ & $15: 00$ & $16: 00$ & $17: 00$ \\
\hline Value $(\%)$ & $00: 00$ & $00: 00$ & $00: 00$ & $00: 00$ & $40: 00$ & $50: 00$ \\
\hline Hour & $18: 00$ & $19: 00$ & $20: 00$ & $21: 00$ & $22: 00$ & $23: 00$ \\
\hline Value $(\%)$ & $25: 00$ & $45: 00$ & $55: 00$ & $55: 00$ & $85: 00$ & $95: 00$ \\
\hline
\end{tabular}

\section{Conclusions}

The study showed that interzonal heat loss occurs in the building between the hours of 8:00-17:00 mitigating the effect of the rising outside temperatures which peak at $34{ }^{\circ} \mathrm{C}$ during these hours. The study also showed that the coefficients of heat transfer at the left and back elevations of the compound house, at its best orientation of $12.5^{\circ}$ from the North, are higher than the front and right-side elevations. While these coefficients are $-0.70 \mathrm{~W} / \mathrm{m}^{2}{ }^{\circ} \mathrm{C}$ and $-0.74 \mathrm{~W} / \mathrm{m}^{2}{ }^{\circ} \mathrm{C}$ at the back and left side elevations respectively for the indirect solar, they are $-0.53 \mathrm{~W} / \mathrm{m}^{2}{ }^{\circ} \mathrm{C}$ at the front and right elevations. Likewise, the interzonal heat transfer coefficients are $-0.21 \mathrm{~W} / \mathrm{m}^{2}{ }^{\circ} \mathrm{C}$ and $-0.51 \mathrm{~W} / \mathrm{m}^{2}{ }^{\circ} \mathrm{C}$ for the front and right side elevations and an average $-0.5 \mathrm{~W} / \mathrm{m}^{2}{ }^{\circ} \mathrm{C}$ for the back and left elevations; as a result, the right, followed by the front elevations, have the lowest insolation. In view of this, residents in the Yoruba one-dwelling compound house move along the veranda in response to temperature changes unlike the Afghan and Iranian cases—which are multi-dwelling compound houses-where response to weather and temperature variation is by housing adjustments across dwellings. The study concludes that user's lifestyle complements the thermal performance of rammed earth Yoruba compound house to cope with discomfort hours in the building.

Author Contributions: O.S.F.: Conception; designed the analysis; interpretation of the analysis; writing; revising the manuscript. M.T.A.: Analysis; interpretation; software; writing.

Funding: This research received no funding.

Conflicts of Interest: The authors declare no conflict of interest.

\section{References}

1. Mofidi, S.M. Methodology for Selection of Climatic Settlements in the Study of Urban Form History. In Proceedings of the Research in Built and Human Environment, Salford, UK, 14-16 March 2001; Sun, M., Aouad, G.H., Eds.; pp. 175-185.

2. Korboe, D. Family-Houses in Ghanaian Cities: To be or not to be? Urban Stud. 1992, 29, 1159-1171. [CrossRef]

3. Li, Y.; Xu, P. Thermal Mass Design in Buildings-Heavy or Light? Int. J. Vent. 2006, 5, 143-149. [CrossRef]

4. Stazi, F.; Vegliò, A.; Di Perna, C.; Munafò, P. Experimental comparison between 3 different traditional wall constructions and dynamic simulations to identify optimal thermal insulation strategies. Energy Build. 2013, 60, 429-444. [CrossRef]

5. Di Perna, C.; Stazi, F.; Casalena, A.U.; D'Orazio, M. Influence of the internal inertia of the building envelope on summertime comfort in buildings with high internal heat loads. Energy Build. 2011, 43, 200-206. [CrossRef]

6. Rossi, M.; Rocco, V.M. External walls design: The role of periodic thermal transmittance and internal areal heat capacity. Energy Build. 2014, 68, 732-740. [CrossRef]

7. Kvisgaard, B.; Collet, P.F. Occupants' influence on air change in dwellings. In Proceedings of the 7th AIC Conference, Stratford-upon-Avon, UK, 29 September-2 October 1986.

8. Evola, G.; Marlettaa, L.; Costanzoa, V.; Carusoa, G. Different Strategies for Improving Summer thermal comfort in heavyweight traditional buildings. In Proceedings of the 6th International Building Physics Conference, IBPC, Torino, Italy, 14-17 June 2015. 
9. Pereira, F.P.; Ramosa, N.M.M.; Almeida, M.S.F.; Simõesa, M.L.; Barreiraa, E. Occupant influence on residential ventilation patterns in mild climate conditions. In Proceedings of the 11th Nordic Symposium on Building Physics, NSB, Energy Procedia, Trondheim, Norway, 11-14 June 2017; pp. 837-842.

10. Rapoport, A. The nature of the courtyard house: A conceptual analysis. Tradit. Dwell. Settl. Rev. 2007, 18, $57-72$.

11. Osasona, C.O. Vernacularizing Nigeria's Contemporary Architecture: You Can Eat Your Cake and Have it! Inaugural Lecture Series 288; Obafemi Awolowo University Press: Ile-Ife, Nigeria, 2016.

12. Kazimee, B.A.; Mcquillan, J. Living Traditions of the Afghan Courtyard and Aiwan. Tradit. Dwell. Settl. Rev. 2002, 13, 23-34.

13. Abdallaha, A.S.H. The Influence of Urban Geometry on Thermal Comfort and Energy Consumption in Residential Building of Hot Arid Climate, Assiut, Egypt. In Proceedings of the 9th International Symposium on Heating, Ventilation and Air Conditioning (ISHVAC) and the 3rd International Conference on Building Energy and Environment (COBEE), Tianjin, China, 12-15 July 2015.

14. Steemers, K.; Ramos, M.; Sinou, M. Urban Diversity, Environmental Diversity in Architecture; Spon Press: New York, NY, USA, 2004; pp. 85-100.

15. Fashuyi, S.O.; Olotuah, A.O. Technology and cultural specificity in housing. An appraisal. In Proceedings of the International Conference of Science and Technology, Akure, Nigeria, 1-3 September 2005; pp. 904-907.

16. Dmochowski, Z.R. An Introduction to Nigerian Traditional Architecture; Ethnographica Ltd: London, UK, 1990.

17. Izomoh, S.O. Nigerian Traditional Architecture; S.M.O. Aka and Brothers Press: Benin City, Nigeria, 1994.

18. Berge, B. The Ecology of Building Materials; Architectural Press: New York, NY, USA, 2009.

19. Taylor, P.; Luther, M.B. Evaluating rammed earth walls: A case study. Sol. Energy 2004, 76, 79-84. [CrossRef]

20. Tangjuank, S. Thermal insulation and physical properties of particle boards from pineapple leaves. Int. J. Phys. Sci. 2011, 6, 4528-4532.

21. Mohapatra, R.; Mishra, A.; Choudhury, B. Investigations on thermal conductivity of palm fiber reinforced polyester composites. IOSR J. Mech. Civ. Eng. 2014, 1, 48-52. [CrossRef]

22. Manohar, K. Experimental Investigation of Building Thermal Insulation from Agricultural By-products. Br. J. Appl. Sci. Technol. 2012, 2, 227-239. [CrossRef]

23. ASHRAE. ANSI/ASHRAE Standard 55-2013-Thermal Environmental Conditions for Human Occupancy; ASHRAE: New York, NY, USA, 2013.

24. Mohamed, M.F.; Prasad, D.; King, S. The impact of veranda on a single-sided naturally ventilated building. Environ. Des. Guide 2010, 1-7.

25. Karava, P.; Stathopoulos, T.; Athienitis, A. Impact of internal pressure coefficients on wind-driven ventilation analysis. Int. J. Vent. 2006, 5, 53-66. [CrossRef]

26. Wang, L.; Xiaohong, L.; Hunter, B. Prediction of the impacts of climate change on energy consumption for a medium-size office building with two climate models. Energy Build. 2017, 157, 218-226. [CrossRef]

27. Li, Y.; Zhao, B.; Zhang, S. Experiment analysis of outdoor air temperature around a single building under the effect of solar radiation. In Proceedings of the International Symposium on Air Conditioning in High Rise Buildings, Shanghai, China, 24-26 October 2000; pp. 360-369.

28. Prianto, E.; Depecker, P. Characteristic of airflow as the effect of balcony, opening design and internal division on indoor velocity: A case study of traditional dwelling in urban living quarter in tropical humid region. Energy Build. 2002, 34, 401-409. [CrossRef]

29. Prianto, E.; Depecker, P. Optimization of architectural design elements in tropical humid region with thermal comfort approach. Energy Build. 2003, 35, 273-280. [CrossRef]

30. Givoni, B. Man, Climate and Architecture, 2nd ed.; Van Nostrand Reinhold: New York, NY, USA, 1981.

31. Aldawoud, A. Thermal performance of courtyard buildings. Energy Build. 2008, 40, 906-910. [CrossRef]

32. Wang, L.; Wong, N.H. The impacts of ventilation strategies and facade on indoor thermal environment for naturally ventilated residential buildings in Singapore. Build. Environ. 2007, 42, 12.

33. Amole, B.; Korboe, D.; Tipple, G. The family house in West Africa: A forgotten resource for policy makers? Third World Plan. Rev. 1991, 15. [CrossRef]

34. Johnson, R. European Cloth and "Tropical" Skin: Clothing Material and British Ideas of Health and Hygiene in Tropical Climates. Bull. Hist. Med. 2009, 83, 530-560. [CrossRef]

35. Clark, W.; Onaka, J. Life cycle and housing adjustment as explanations of residential mobility. Urban Stud. 1983, 20, 47-57. [CrossRef] 
36. Ecotect Simulation Software. Autodesk; 2011, version 1.0, California, USA.

37. Moquin, M. Ancient solutions for future sustainability: Building with adobe, rammed earth, and mud. Adobe J. 1994, 4, 543-552.

38. Akpabio, L.E.; Ekpe, S.D.; Etuk, S.E.; Essien, K.E. Thermal properties of oil and raffia palm fibers. Glob. J. Pure Appl. Sci. 2001, 7, 575-578.

39. International Standard Organization. ISO EN77304. Moderate and Thermal Environment-Determination of the PMV and PPD Indices and Specification of the Conditions for Thermal Comfort; International Standard Organization: Geneva, Switzerland, 1994.

40. O'Brien, W.; Athienitis, A.; Kesik, T. Thermal zoning and interzonal airflow in the design and simulation of solar houses: A sensitivity analysis. J. Build. Perform. Simul. 2011, 4, 1-18. [CrossRef]

C 2019 by the authors. Licensee MDPI, Basel, Switzerland. This article is an open access article distributed under the terms and conditions of the Creative Commons Attribution (CC BY) license (http://creativecommons.org/licenses/by/4.0/). 